Article

\title{
Muslim Everyday Religious Practices in Austria. From Defensive to Open Religiosity
}

\author{
Jonas Kolb ${ }^{1, *}$ and Erol Yildiz ${ }^{2}$ \\ 1 Institute of Islamic Theology and Religious Education, University of Innsbruck, 6020 Innsbruck, Austria \\ 2 Institute of Educational Science, University of Innsbruck, 6020 Innsbruck, Austria; erol.yildiz@uibk.ac.at \\ * Correspondence: jonas.kolb@uibk.ac.at
}

Received: 30 January 2019; Accepted: 4 March 2019; Published: 6 March 2019

\begin{abstract}
Although Muslim groups in the population comprise an integral component of Austrian society, the public image of Islam tends to be generally negative. In the meantime, there are now significant successor generations of Muslims who, in contrast with their parents' generation, have other religious orientations and positionings, and have become hybrid, heterogeneous individuals with 'multiple-home' attachments living in Austria. Nonetheless, in public discourse, they appear as a homogeneous group. Our study is based on a change in perspective, shifting front and center the religious orientation of these persons as seen from their own perspective and experiences. The findings of our study on Muslim diversity in Austria show just how differentiated, complex, ambivalent, and hybrid the everyday religious practice of individuals directly on the ground is or can be. In the following article, the focus is on a form of open religiosity that is practiced above all by members of the successor generations.
\end{abstract}

Keywords: open religiosity; defensive religiosity; religious practice; everyday life; Muslim diversity; Austria; mixed-methods study; European Islam

\section{Introduction}

The Muslim population in Austria has increased markedly in recent decades. An extrapolation in 2017 estimated their number at some 700,000 (Goujon et al. 2017, pp. 7, 13). However, despite the long history of Islam and existence of Muslims living in Austria, and their pronounced presence in the media and the discourses associated therewith, the actual life realities of the Muslim population have largely received little attention to date. Predominant in relevant academic research studies, analogous to inquiry in other European countries, is a focus on the confrontation with organized Muslim structures, associations, and facilities (Amiraux 2006, p. 21; Jeldtoft and Nielsen 2011, p. 1113). A consequence of this is that the Muslim presence in the media and the public sphere has been reduced to religious activities taking place specifically in the mosques. By contrast, there has been little interest in the everyday religious practice of the preponderant majority of the Muslim population in the country (Heine et al. 2012, p. 21).

This notwithstanding, in public reporting in the media in Austria, as generally in other European countries, Muslims tend to usually appear in contexts beset by problems (Yildiz 2018). That also is the case with members of the second and third migration generations, i.e., those who were born and raised in Austria. For years now, catchwords such as lack of orientation and deficient integration, a parallel society, propensity for violence, religious fundamentalism, archaic images of woman and religiously motivated terrorism have been part and parcel of the standard vocabulary in political and media debates and are often reiterated in discourse in connection with Muslims (Kolb 2017, p. 74). Frank-Olaf Radtke has noted: 
"Social conflicts that can be associated with 'culture' and 'religion' are given greater public attention and are prone to relatively rapid politicization. They are accorded a potential for conflict that from the outset appears to fulfill the criterion of political relevance and make them candidates for dialogues external to everyday life". (Radtke 2011, p. 98)

Likewise, in view of these ascriptions in the media, a reductive perspective on the Muslim population gives rise to the impression that they comprise a homogeneous group of believers who consistently represent and practice their religion in the same manner (Yildiz 2018). The present paper seeks to counter such generalizations and, based on an extensive and detailed empirical investigation, to foreground the diversity and multidimensionality of the everyday religious practice of Muslims. We counter cliché-ridden conceptions about Islam and Muslims in Austria by presenting a picture that is differentiated and grounded in the concrete everyday reality of their lives.

In the framework of our article, we work out the contours of a form of religious practice that we designate as 'open religiosity'; it shows convincingly that to be highly religious is, in fact, varying and diverse. To date, this phenomenon has received but scant attention. This open form of religious practice clearly exemplifies and points up just how differentiated and multifaceted that segment of the Muslim population marked by strong religious ties and a pronounced degree of religiosity actually is. That is because the distinctive features of the religiosity of these believers are distinguished by an individual, self-determined approach to religious regulations and norms, while they reject a rigorously rule-bound, conscientiously dutiful understanding of religion.

The common shared features among the representatives of this form of practice comprise a certain distance from the obligating character of the traditional religious pillars of Islam and a self-determined, emancipated manner of dealing with existing Islamic religious regulations and norms. But the reverse conclusion, namely that the ritual practices (obligatory prayers or Friday prayers) in the context of open religiosity are totally sidelined and neglected is incorrect. Such practices are performed, however not consistently and continually, and not always at the ritually prescribed times, but rather in keeping with a person's individual need for a nearness to God.

This mode of practicing religiosity is common principally among members of the second and third migration generation, and thus among individuals who have been born and raised in Austria. This gives rise to a special relevance of this form of religious practice for the future. That is because the number of Muslims belonging to the successor generations will significantly increase in the years to come. The consequence will be that what we have termed open religiosity will impact upon and stamp the character of everyday Muslim life in Europe ever more strongly than in the past.

Our analysis builds here on the findings of other research dealing with the forms of religious behavior by members of the successor generations in the German-speaking area. Worth noting in this regard are studies by Klinkhammer (2000), Ornig (2006), Khorchide (2007) and Gennerich (2016) that deal with the distinctive character of religiosity as practiced by younger Muslims and have shed light on deviations from religious practice common among an older Muslim demographic. The analysis by Özıșık (2016) provides special insights in working out the salient processes of development between three generations of different Turkish families in the German-speaking area. It becomes evident that there has been a shift in the second and third generation to a more pronounced dialogic openness and that predominant is a functional understanding of religion. In particular, in the third generation, research has uncovered a greater presence of individualistic aspects in lifestyle and religious forms of behavior.

Yet this does not at all mean that there is a process underway of self-distancing from religious questions within the successor generations. Rather what we find is that the motives and reasons underlying religious practices become more individualized, as also pointed out by Nikola Tietze in her comparative study on young Muslims in Germany and France (Tietze 2001). Thus, for example, there can be different causative factors for why a previously non-religious young person turns increasingly toward Islam, or why a young woman born and raised in Germany within a secular family environment suddenly chooses to wear a headscarf (hijab) against the will of her parents. In his ethnographic study 
on the Islamic association Milli Görǚs in Germany, Werner Schiffauer shows that intergenerational developmental processes do not only occur inside a family, but rather that within one and the same religious organization, depending on the generation, different approaches can predominate toward religion. Members of the first migration generation are often characterized by what can be termed a 'defensive religiosity'. Such a notion of religiosity is determined by the wish to counter concerns and worries about losing one's personal sense of identity in the diaspora, and by the fear of alienation from one's own cultural roots. As a result, the individuals concerned often turn their backs on the majority society and practice their religious customs in a ritualized as well as secluded manner. Contrasted with this, it is found that in the successor generations, a diasporic identity increasingly emerges, characterized by open, consciously reflexive features (Schiffauer 2010, p. 360).

Thus, the plans and designs for life and religious orientations of the successor generations differ significantly from those of their parents or grandparents, because they do not have the same experiences of migration. They were born and bred in Vienna, Graz or Innsbruck and experienced their own processes of socialization. Nevertheless, they are still perceived as migrants or persons coming from a migration background. In confrontation with this public practice of labelling and discriminatory social conditions, the individuals concerned develop their own religious orientations and biographies, which for their social positioning are of great relevance.

Through the prism of open religiosity, we will seek to shed light here on the possible differential content of the everyday religious practice of members of the second and third migration generation. Before we deal with an analysis of the forms of practice, in the following section we will initially describe in greater detail the underlying empirical study our present paper is based on. We will then proceed to sketch the typology of everyday religious practice among Muslims in Austria as reconstructed in our investigation. Subsequently, we examine open religiosity by illuminating its characteristic features, likewise by drawing on statements by interviewees, and by analyzing the socio-demographic backgrounds of the believers here under study.

\section{Theoretical Perspectives: Muslim Everyday Religious Practice}

In recent years, Islam and the Muslims have been constructed and essentialized ever more as veritable prototypes of the stranger, the outsider, the Other in the Western world. That is true not only of the media and in public reportage and discourse but has also permeated into the fabric of scientific methods and theoretical perspectives. The consequence is that in studies on migration, what is often commonplace are dichotomous, binary juxtapositions and collectivizing images, conjunct with the pattern of 'us' (Christians) and 'them', the 'others' (Muslims), along with generalizing interpretations ('practicing' vs. 'secular' Muslims) (Yildiz 2018, 2019). However, such alienating points of view exclude the perspectives of the people involved and misjudge, on one hand, the differing meanings that religious aspects can have in shaping the lifestyles of individuals. On the other, ambivalent, hybrid or multiple-home attachments and affiliations are strictly blocked out in such readings. By contrast, there is little realization that religiosity is only one possible reference point amongst many for the self-images and identity of the individuals concerned and their respective patterning of personal everyday life. This clashes strongly with the social embedding and multifaceted character of self-images, as Navid Kermani, for example, has paradigmatically noted:

"Yes, I'm a Muslim—but I'm also much more too. The sentence 'I'm a Muslim' thus becomes false, indeed downright ideological, when I define myself exclusively as a Muslim, or am so defined by others". (Kermani 2009, p. 19)

Viewed against this backdrop, in our empirical study we shift to a new perspective that opens up a window onto new epistemic horizons. Analogous to Nilüfer Göle in her study "Europäischer Islam. Muslime im Alltag" (2016), we distance ourselves from artificial, preconceived classifications, and instead take as the point of departure for our investigation the standpoint of ordinary, "very simple everyday Muslims" or "ordinary citizens" (Göle 2016, pp. 13, 15) and their ways of dealing with 
religion. Through the lens of a practice-theoretical approach, we seek to take seriously the concerns of the individuals, and on this basis to reconstruct subjective interpretations of religiosity in everyday life and connections between the individual interpretations. Correspondingly, at the center of theoretical perspectives in our study is Muslim everyday religious practice.

By this, we mean not only religious attitudes and convictions. We are not just referring to whether the individuals concerned eat pork or not, drink alcohol or not. In order to arrive at a comprehensive and differentiated picture of what the religiosity of Muslims comprises, we draw on the classic model proposed by Charles Y. Glock in regard to how religiosity can be analyzed looking at a range of differing aspects (Glock 1969). Relevant here are five dimensions of religiosity: religious experience, the ritual dimension, religious ideology, religious knowledge and consequences. Of central salience in our conception is the dimension of religious consequences. We conceive of that as encompassing the practical consequences of the shaping and manifestation of religiosity on its various different levels. The dimension thus includes all the different aspects pertaining to the visible ways of dealing with religion in everyday life and behavior and aspects that shape the interpersonal interactions of the individuals involved. This level thus revolves around the question: what does a person do or refrain from doing as a consequence of his/her religiosity in their design for everyday life and lifestyle, i.e., at work, in the bosom of the family and within their circle(s) of friends and acquaintances.

Along with the multiple-level model of Glock, we also pursue a conceptually guided, open-ended approach to our object of investigation, one corresponding to the attitude of lived religion (Orsi 1985; Hall 1997; Ammerman 2007; McGuire 2008). We thus basically conceive of religiosity as something that is dynamic and in flux, arising in the framework of everyday practice, developing in close interconnection with social background, regional origin and the cultural context. The specific character of the religiosity of the Muslim population in Austria can only be revealed through an open approach to how religion is concretely translated into everyday practice, religious perspectives, understandings and interpretations. Thus, central here are less theological positions, content and debates. Rather what is salient is how Muslims view and perceive their faith, what meaning Islam has for them, how they deal therewith in their everyday life, and how this impacts on their designs for living (Dessing 2013; Nielsen 2013).

In other words: the religious designs for living and practices are taken as the point of departure for theoretical reflections, however without excluding the social conditions and asymmetrical relations of power involved. The religious orientations are constantly marked by structural obstacles and modes of discrimination. These two phenomena, the restrictive conditions for living, subjective spaces of possibility and the everyday religious practices are interconnected conceptually and investigated from this vantage point.

\section{Methodological Concerns and Explanations Pertaining to the Data}

The empirical data that the present paper is based on was gathered in the framework of our study "Muslim Milieus in Austria", carried out between 2012 and 2016 (Aslan et al. 2017). This research involved a mixed-methods study, entailing a qualitative and quantitative investigation. Both approaches focused on the same phenomenon, mutually supplementing one the other: the nature of everyday religious practice among Muslims in Austria. The study design follows the logic of exploratory designs as developed in John W. Creswell's terminology (Creswell and Clark 2007, p. 75).

In the qualitative study, we questioned 70 Muslims across Austria, utilizing qualitative, semi-structured interviews. In the quantitative part, our sample comprises 650 persons, interviewed face-to-face using a standardized questionnaire. While we worked in the qualitative study portion with a qualitative sampling scheme (Schreier 2010), in the quantitative investigation, by contrast, we implemented a staggered, step-wise quota sampling procedure (Diekmann 2010, p. 390).

In the sampling, we took into account all persons as potential interviewees-and thus members of the basic totality under focus-who refer to themselves as Muslims, no matter how strong or weak their concrete faith and religiosity are. The reason for such an approach is that from a social-scientific 
perspective, how to actually classify who is or is not a Muslim is by no means clear and unambiguous (Amiraux 2006; Jeldtoft 2009; Spielhaus 2011). It is not always univocal to what extent the affiliation with one of the various currents in Islam is constituted by means of birth, family background or a self-determined decision of one's own. In implementing our empirical survey, we utilized the preliminary question asked as a criterion: namely whether the interviewee would identify him/herself as a Muslim in connection with a census or other statistical survey in Austria. This approach was adopted so as to avoid any unintended pre-selection of interviewees and also to correspondingly encompass within the sample so-called non-organized and unaffiliated Muslims. The latter includes such persons who have no close connection with mosque associations or Muslim organizations and who at times only rarely or never enter a mosque or prayer hall.

At first glance, this may seem like an unimportant marginal aspect, but on closer scrutiny it emerges as of especial importance. That is because this group makes up the overwhelming majority of the Muslim population in the German-speaking area, some 80 percent (Bundesamt für Migration und Flüchtlinge 2009, pp. 167, 170; Heine et al. 2012, p. 65). In order to avoid an unintended pre-selection (and thus imbalance) among those to be interviewed, and also with an aim to take into proper account in the sample the broad majority of the non-organized Muslims, persons who are not involved in any religious organizations, a conscious effort was made in recruiting interviewees to avoid an approach proceeding via the intermediary of religious institutions such as mosque associations (Aslan et al. 2017, p. 51).

\section{Sketch of the Typology}

The qualitative and quantitative surveys, which examine Muslim everyday religious practice from different perspectives, were each evaluated separately and then combined with one another. After that, a typology was developed that distinguishes between the various different forms of religious practice, and in which both qualitative and quantitative aspects were taken into due account. In our analysis, what we term a 'form of practice' is a specific, characteristic expression of Muslim everyday religious practice that can be distinguished from other forms of behavior in the way persons deal with religious questions.

The forms of religious practice are grounded here on two dimensions of comparison: on one hand, the intensity of religiosity in everyday life, and on the other, the orientations of social value. Dealing with religiosity encompasses religious convictions and experiences, theological knowledge, the practical performance of religious rituals and regulations, as well as orienting and shaping everyday life in accord with religious rules. By contrast, orientations of social value, as based on the Portrait Value Questionnaire (PVQ) of Schwartz (Schwartz et al. 2001), move in a space between the extremes of openness for change and the preservation of what exists. These are attached to positions regarding value orientations (such as self-determination, hedonism, safety or conformism), family images, concepts of education, gender-specific role images and attitudes vis-à-vis social or cultural traditions.

In the multi-perspectival analysis, forms of religious practice were subdivided into five categories. A distinction was made between a conservative, tradition-preserving religiosity, a pragmatic religiosity, an open religiosity, a religiosity as a cultural habit/custom and a free residual religiosity. The different forms of practice are distributed with differing degrees of frequency. Their numerical distribution in the total sample is as follows: pragmatic religiosity is practiced by $29.6 \%$. This is the form of religious practice adhered to by the largest group in the total sample, followed by religiosity as a cultural habit/custom at $26.6 \%$. The forms of practice of free residual religiosity (15.0\%), tradition-preserving, conservative religiosity $(14.1 \%)$ and open religiosity $(14.8 \%)$ round out the picture.

Figure 1 shows the position of the five different behavioral forms of dealing with religiosity and their closeness of connection one to the other. 


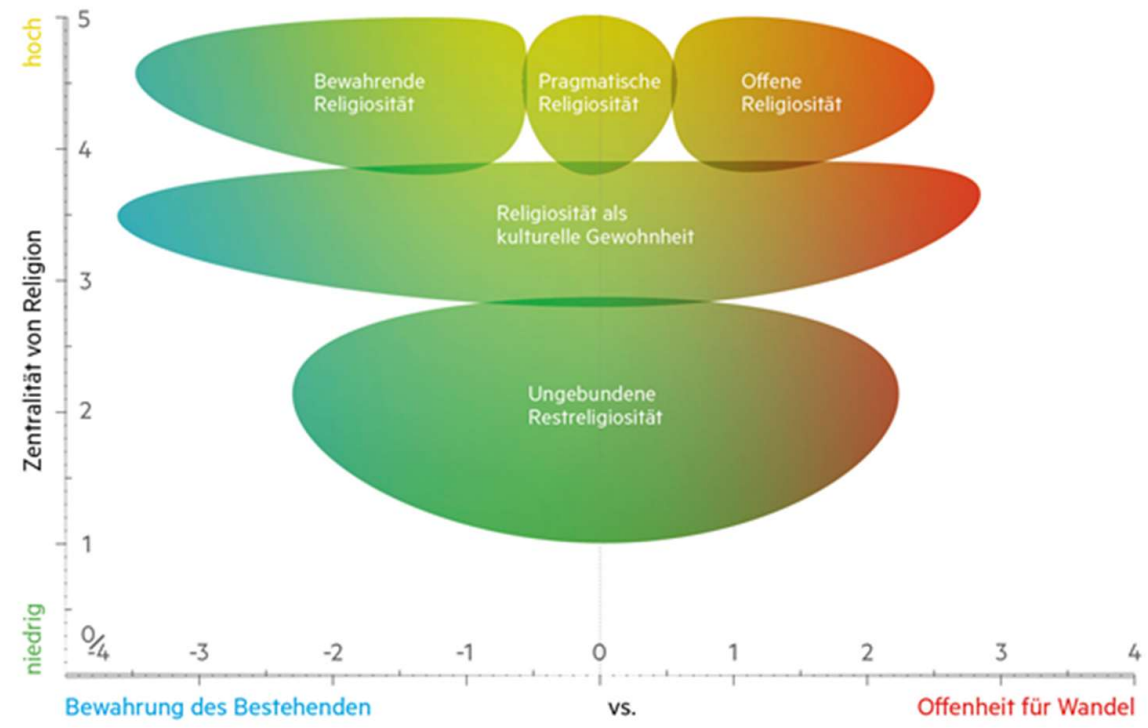

Figure 1. Positioning of the five forms of religious practice in the system of coordinates along the axes centrality of religion and openness to change vs. preservation of what exists ${ }^{1}$.

The positioning and extent of the forms of religious practice indicate on one hand the intensity of religiosity and of the basic orientations of value, and on the other the group-internal homogeneity and breadth of variation of the forms of practice. The intensity of religiosity (y-axis) is determined using the centrality scale of Huber (2003), which measures the different levels of religiousness/religiosity, extending from a minimum of 1.0 to a maximum of 5.0. Orientations of social value are expressed in line with the continuum 'Openness to change vs. Preservation of what exists' ( $x$-axis), extending on a scale from -4.0 to +4.0 . While negative values indicate that a preservation of what traditionally exists is more strongly expressed, positive values in the scale mark an openness to change.

In analyzing the empirical data, two forms of dealing with religion in everyday life proved possible to identify, characterized by a tendency to be more distanced from religion. They comprise religiosity as a cultural habit/custom (mean value on the $\mathrm{Z}$ scale of 3.5) and the free or unbound residual religiosity (mean value: 2.2). In the framework of the present paper, these two forms of practice, characterized by a relatively low degree of religiosity, will not be discussed in any further detail.

Alongside tradition-preserving religiosity and pragmatic religiosity, there is a further form of religious practice that can be termed highly religious, as based on the classification via the Z-scale: namely open religiosity. With a mean value of 4.4, this ranks only marginally below the degree of religiosity of the two other highly religious forms of practice (tradition-preserving religiosity: 4.7; pragmatic religiosity: 4.5). However, in comparison with all other forms of dealing with religion, it is distinguished by the fact that especially strong and robust positions which are liberal, cosmopolitan, self-determined and oriented to experience are represented here. While in the conservative, tradition-preserving religiosity features of a defensive understanding are present, open religiosity reveals a very different viewpoint, namely an open and self-determined approach to questions of faith and attitudes. Thus, on the scale of orientations of social value, this achieves the highest value at +1.17 , and consequently the most striking and prominent degree of openness to change.

1 The German expressions in the graphic correspond to the following English terms: $x$-axis-Bewahrung des Bestehenden (Preservation of what exists) vs. Offenheit für Wandel (Openness to change); $y$-axis-Zentralität von Religion (Centrality of religion), niedrig (low) vs. hoch (high); five forms of religious practice: Bewahrende Religiosität (tradition-preserving religiosity), Pragmatische Religiosität (pragmatic religiosity), Offene Religiosität (open religiosity), Religiosität als kulturelle Gewohnheit (religiosity as a cultural habit/custom), Ungebundene Restreligiosität (free residual religiosity). 
In the following sections, we deal in requisite detail with open religiosity. This form of religious practice tends to go unmentioned in public reportage, likewise because in social-scientific debates to date, one can scarcely find any certain, well-established findings in respect to this specific form of Muslim everyday religious practice. To describe this form of practice, we will utilize both qualitative and quantitative data, where the former are accorded central salience and importance.

\section{Open Religiosity: Its Forms of Practice}

\subsection{Socio-Demographic Backgrounds}

In the total sample, open religiosity at $14.8 \%$ is one of the smaller segments. Characteristic of this form of practice is the combination of a high degree of religiosity with liberal, cosmopolitan value orientations. From a demographic perspective, the linkage of these two orientations can be found more frequently among younger Muslims. This is reflected in the fact that persons who represent this form of practice have an average age of 28.9 years, markedly younger than the average age of 35.1 years for the sample as a whole. Consequently, open religiosity is more a phenomenon of youth and present among younger adults who desire to put religious norms and regulations to the test. By contrast, older interviewees, especially after establishing a family, often tend more strongly toward espousing traditional values and preserving what conventionally exists (Gennerich 2010, p. 54). This in turn also impacts on the expression of their everyday forms of religious practice. That proves that everyday religious practice is interconnected with the respective concrete life situations of the persons involved.

Interestingly, in regard to the question of gender-related distribution and representatives of open religiosity, it is apparent that females are far more strongly represented. In the segment of open religiosity, there is a female preponderance of $60.7 \%$ over against $39.3 \%$ male. By comparison, in the total sample, the distribution is almost equal ( $51.2 \%$ male, $48.8 \%$ female). Such a pronounced gender imbalance is not evident in connection with any other form of religious practice. Openness to change is thus principally an attitude that appears more often among female Muslims.

Regarding citizenship, the majority of $58.4 \%$ possess an Austrian passport, followed by those with Turkish nationality (14.6\%) and Bosnian citizens (4.5\%). A glance at the place of birth reveals that almost half the individuals who represent this form of religious practice, $41.4 \%$, were born in Austria, and thus are members either of the second or third migration generation. In the total sample, by comparison, their proportion (born in Austria) is far smaller, 31.6\%. This serves to confirm a finding of Weiss and Strodl (2016, p. 73) that in the second-generation religious practices and traditions suffer a partial loss in binding power or also undergo transformation. This circumstance is also reflected in the fact that interviewees are more strongly oriented toward values of self-realization and stimulation if their own parents grew up in Austria.

In respect to level of educational achievement, the representatives of open religiosity differ little from those in the total sample. The level of education is neither uniform, nor does it exclusively contain individuals with more advanced levels of completed education. Rather, as in the case of other forms of religious practice as well, there is a high level of internal group diversity.

\subsection{Subjective Needs and Social Conditions of Life}

As was explicated in the theoretical section, the subjective needs and orientations must be conceptualized in conjunction with the social conditions of life. The form of practice of open religiosity is a manifestation of Muslim everyday practice that due to its openness for change is marked by special features. ${ }^{2}$ Compared with the conservative and also the pragmatic modes of religiosity, open religiosity, which likewise can be classified as 'highly religious', is clearly distinct. Alongside a high

2 Göle (2016) arrives at similar findings in her comparative study on the everyday life of Muslims in different European countries. 
degree of religiosity, it is additionally characterized by basic orientations and adherence to values that are personally liberal and cosmopolitan. Thus, in this form of religious practice, cultural traditions are accorded high value and preserved; yet at the same time, there is an openness toward other models that deviate from traditional patterns of living and social relationships. This is evident, for example, in the striking fact that the individuals concerned occasionally have durable personal relationships with a partner and live together with him or her, yet without any formally legal marriage.

There are also differences when compared to the other highly religious forms of practice in respect to the predominant approach to religion as such. In open religiosity, that approach is not principally guided by strongly conscientious adherence to rules and regulations, as in the case of tradition-preserving practice-and albeit with some adjustments, also in the case of pragmatic religiosity as well. Rather, it is based more on individual needs, a personal search for meaning or the desire for a spiritual mainstay, a solid footing in life. Yet in the case of open religiosity, significantly there is no trace among its adherents as investigated of a pejorative, negative attitude toward other religions, or an exclusivistic understanding of religion that seeks to dismiss the claim to truth and validity of the interpretations of other religions.

This approach to religion is reflected in the example of the interviewee Selma, a 27-year-old student who grew up in Vienna and is resident there; her parents stem from the Sandžak region in Serbia. Selma describes her religious self-positioning in the following words:

“To be a Muslim is a kind of identification, so, like it's a part of my identity. A very basic part. If Allah weren't there [ ... ], I'd just be lost. So that is something that constitutes my very being, my life, and above all is a source of personal strength. I mean, without my religion I'd simply be a weak person. And somehow, I'd be without any direction, $I^{\prime} d$ have no goals in life, and above all, my life would also seem meaningless." (Selma ${ }^{3}$ )

For Selma, to be a Muslim woman is a central component of her self-image, without which she would no longer be able to see any goals in her life or the sense and meaning of her existence in this world. It is clear here that the young woman explains her religiousness and the practical adherence in everyday life to her faith principally by reference to individual personal needs. Religiosity for her is imbued with a meaning-making role in her daily life and constitutes a vital source of profound inner strength.

For Alma, a 32-year-old Carinthian woman with a migration family background from Bosnia, her Muslim religiosity is likewise an integral component of her self-image. This mother of three, who works as an employee in the wellness sector, can likewise be classified as highly religious in orientation. Yet present in her religious self-positioning as she expresses it are also critical tones, as when she notes that Allah or religious faith are not constantly present in her mind around the clock:

"I was born a Muslim, so that's how I came into this world, and I'm also very proud of that. But, well, like I don't exaggerate it, and also, in general, I don't exaggerate anything in life. I know what I am and am happy to be who I am. Yet I also respect everyone else. [ . . . ] Yes, I do very often think of God. Like when something happens, I think to myself: 'That was fate' or 'That was due to a higher power from above!' But like it's not the case that I'm thinking about God $24 \mathrm{~h}$ a day." (Alma)

Being Muslim for Alma is a central building block of her identity. Nonetheless, this mother of three has certain reservations: religiosity for her is not present $24 \mathrm{~h}$ a day; she thinks sometimes more about God, sometimes less, depending on the situation in everyday life in which she finds herself at the moment. Being Muslim for Alma is thus not something she identifies with totally and

3 The names of the Muslims interviewed were rendered anonymous in such a way that the pseudonyms allow for conclusions as to the regional origin of the interviewees. 
exclusively. Rather it is one building block of her self-image and identity among various others. Alma consciously distances herself from Muslims who in her eyes exaggerate their religiosity (as expressed subliminally in the quoted text). So, she explicitly distances herself from the form of practice of conservative religiosity; she appears to feel a certain sense of dislike for it, even though she herself is highly religious. She simply practices her religiosity in everyday life in a different way, namely less in adherence to the form of religious rules and regulations, which she by no means rigidly follows-but rather above all on the level of her religious convictions, in the form of a personal piety and spirituality as well as in the form of personal prayer.

\subsection{Self-Determined and Emancipated Religious Practice}

In respect to religious ritual, in the form of practice of open religiosity there is a reserved attitude toward religious rules and regulations. This is a defining feature of this form of everyday Muslim religious practice. This reserved, more reticent attitude toward religious obligations is expressed with particular clarity by Selma, the above-cited 27-year-old, for whom the reciting of traditional ritual prayers is not by any means seen as the fulfillment of a binding religious obligation. She says:

"The ritual prayer is a kind of spiritual experience, or something where you sort of put yourself in a kind of trance. Not intentionally, but it's simply like that. And that's why I simply would like, or it's important for me that things are just quiet. Yes. Yes, but otherwise it has to be, and right, yes well, naturally I put on my headscarf and everything, that's clear [... ] because when I pray, I'm like so very near to God. There's also the passage in the Quran that says we're closer to man than his jugular vein. So, actually, God is so very close to us humans. You just feel that very strongly in such a ritual prayer, like that, above all that's how I feel it is. Yes." (Selma)

Far from regarding the performance of ritual prayers as an iron-clad obligation or an act of paying a debt, expiating for some guilt incurred — she categorically rejects this notion-for Selma her focus is on spiritual experience, a religious state of being in a kind of trance and a nearness to God that she experiences when praying. Self-determination is a central building block in the understanding of religion and faith:

"So, for me, the five religious pillars are a signpost, something an individual can stick to in order to try to be a good person. I'm also not the sort of person who always makes up for prayers neglected. No, I don't do that. Because it just has no meaning for me at that moment." (Selma)

Thus, her recitation of the ritual prayers is bound up with the circumstance that in the given moment of prayer their meaningfulness is perceived, which for her springs solely from a subjective felt need and corresponding mood at the time. This attitude is far removed from any distancing on her part from religious rules and regulations. Rather, it is due far more to the underlying desire for direct personal closeness to God-which in her mind simply could not be achieved by adhering to religious duties and commandments such as the obligatory prayers. In the light of that, for her, the five religious pillars are signposts or guideposts that can be followed and paid heed to in the personal quest for meaning, but do not necessarily have to be observed. ${ }^{4}$

Yet for her the principal concern is to tread down a self-determined path liberated from the rules and regulations in dealing in everyday religious practice with the obligatory prayers:

4 There are certainly Sufi borrowings or analogies in the search for religious experiences, the meaning of faith and spirituality, as well as in the partial turn away from ritual norms and adherence thereto. Nevertheless, open religiosity must be understood as an entirely independent form of religious practice, since the social conditions of context and life of Muslims who practice a mode of open religiosity differ totally from those associated with traditional currents in Sufism. 
"So, well, I must honestly say that I'm someone who basically always prays only when I have need for it $100 \%$ and am convinced and certain about it. I'm not a person who follows and observes rules and regulations, like praying five times a day. I only do that when I have the feeling that I have to, that I must pray five times a day. But not because there's this regulation." (Selma)

Adherence to religious commandments or duties is diametrically opposed to this young woman's conception of religion. She herself arranges her everyday religious practice autonomously in line with her personal needs, i.e., geared to whether she senses the need at the time for the spiritual experience that is connected with the performance of the ritual prayer. She recites the obligatory prayer when she feels the desire for that, and not when it is prescribed by the ritually set times. Generally speaking, in Selma's case, there are no traces of a secluded and defensive religiosity that is practiced above all in the context of mosques or religious associations. Instead, claims are formulated and interpretations made in a self-determined manner. Religious customs are not practiced in order to defend and preserve cultural roots and traditions, but to meet individual needs.

Selma views her emancipative and self-determined way of dealing with religiosity and religious rules in everyday life not only as something legitimate, but in respect to their significance also far more in keeping with the meaning of religion than the dutiful, obligatory, orthodox observance of religious rules and commandments. Thus, she continues, noting:

"I'm also of the opinion, I'm convinced, that God also understands something like that and also values it more, that's what I believe. [ . . . ] I mean, I'm not someone who can somehow make a judgment. Like in some way or other, I also don't want to judge things. Because only God can do that. But it's a totally different approach. Like I realized that myself when I started to pray. It's a totally different approach when you pray because you feel it, and when you want to be incredibly close to God, than when you pray just because there are certain regulations, or when you want to emulate such dogmas." (Selma)

To have to be under a constraint to recite obligatory prayers in the sense of religious duties at a set specified time is something this Viennese woman views as dogma, which for her is a quite problematic concept. She regards dogmas as religious doctrines claiming timeless and universal validity, and which cannot and must not be questioned. And such an understanding constrained by the straitjacket of dogma stands in contradiction with her conception of Muslim religiosity. In her view, she can gain nothing from such a rule-bound religiosity, lived as a mere adherence to and emulation of religious rules and prescriptions.

According to Selma, if the ritual prayers are being solely performed due to a constraint to fulfill an obligation that believers sense, then their meaningfulness and rationale should be questioned. By contrast, she in any case gives priority to a self-determined religiosity springing from personal conviction, even if she actually attempts to avoid a hierarchical categorization of the two forms of religious practice. In this context, she implicitly also rejects takfir practices, i.e., the attempt by highly religious Muslims to deny fellow believers who do not adhere to the religious pillars in their daily lives their very identity as Muslims. Selma fundamentally spurns the notion of pointing judgmentally at other individuals and branding the way they deal with religion as negligent or mistaken. In her view, upon what path the relation and nearness to God are established is a personal matter only between the believer and God. It should not concern outsiders, is none of their business. She believes a judgment about who is a believer, who a non-believer or apostate is solely a concern for the Creator.

In Selma's eyes, religion is a very private matter. However, she thinks that central criteria for a person to show they are religious and a believer are self-reflection, contrition and the admission of one's own errors and transgressions. To explain this, she makes reference to a hadith, i.e., a traditional dictum of the Prophet, from which she derives the following:

“And God forgives the person who has made a mistake. Like, I don't know, well, like he drank some alcohol or who knows what $[\ldots]$. And if the one who did something bad 
repents, God simply sees that. It's important that if you make a mistake, do something wrong, to just repent and display genuine remorse. And that person will enter Paradise. [ ... ] So, for me this is one of those stories that somehow hits the nail on the head: I'm not on earth for that, I can't, in regard to anything holy and sacred here on God's earth, I can't get up and say: 'Yes, you're a pious believer, but no, you over there, you aren't!' Or: 'Hey, that guy, he drinks alcohol, but then he goes to pray in the mosque on Friday!' He'll know for himself what is best, right? And above all, God will know that even better. So I'm not, I mean, my purpose is not that now I should stand there in order to condemn someone." (Selma)

This young woman fundamentally believes that a self-determined and innermost religiosity can only develop in the first place by admitting one's own mistakes, lapses, faux pas or vices and reflecting on them. She says this kind of personal turnaround, changing one's ways, is also valued much more by God, because it means that a person has chosen to venture down the path to a way of life in conformity with religion, and has done so in a self-determined and voluntary manner-differently than in the case of Muslims who, righteous and cognizant of their duty, constantly organize their daily lives solely in accordance with religious rules and regulations.

In this conviction, Selma does not stand alone. It is a frequently expressed and widespread pattern of argumentation among Muslims who disregard religious rules and commandments more or less in their daily lives. They openly admit their transgressions, for example, in order through occasional remorse to give some sort of religious legitimacy to their passionate, pleasurable, more hedonistic style of life.

Alongside rejection of a purely dutiful and regulation-guided understanding of religion, there is, in addition, a pronounced critique of traditional religious norms and doctrines, and also of the Muslim landscape of organizations in Austria among individuals interviewed who profess an open religiosity. But one cannot discern among them any negative attitude of opposition toward the non-Muslim Austrian majority society. Yet for a highly religious form of practice such as open religiosity, there is a surprising openness to accept styles of life oriented to pleasure and experience. The social environment of the persons concerned is also marked by a variety of individuals from diverse religious backgrounds represented there.

The majority of those who practice an open religiosity in their daily lives strongly identify with Austria. Many of those individuals concerned here were in addition born and bred in Austria, they went to school in the country and regard it as their homeland. As a rule, they represent secular orientations and see religiosity as a private matter, a sphere in which no one else-neither the state nor religious organizations-should be allowed to interfere. And they espouse a separation between questions of religion and the state or the realm of politics. They view their future in most cases to be in Austria, although they are vehement in their criticism of how Islam is portrayed in the media and in the public debates about the Muslim population groups in the country. Many of those who practice an open religiosity in their daily lives feel insulted by the way in which their religion, their faith in numerous media reports is always brought into association with terrorist activities, violent incidents and military conflicts. They cannot recognize themselves in any way in such imagery. Rather they feel rejected and their own self-image as Muslim Austrians is repudiated by such media discourse.

\subsection{Limits of Autonomous Interpretations}

But there certainly are limitations to the self-determined interpretation of religious rules and precepts and a religiosity that is based on personal subjective needs, which characteristic features of this form of practice represent. Subjective interpretations can only occur along certain circumscribed pathways. Thus, the emancipative approach to the obligatory prayer is manifested principally in whether the persons involved choose to pray, and when: i.e., in the frequency of their praying, but not in what form this occurs. That form of the set prayer remains largely intact; there is no modification of the ritual sequence, the preparations for it or the essential elements of the obligatory prayer. One of 
the few restrictions open to change is reflected in the fact that some individual female Muslims who adhere to the form of practice of open religiosity do not always honor the wearing of the headscarf as a prescribed regulation and duty for carrying out the ritual obligatory prayer.

Along with the self-determined, autonomous approach to the ritual obligatory prayer, Muslim women who favor open religiosity also engage in an emancipative approach to the Friday prayers. There is repeated criticism that only male Muslims are allowed to participate in the Friday service in the mosque. Selma commented on this as follows:

“Recently I've been going to the Friday prayers, something that previously I never did. Because earlier on I also thought that the Friday prayer is something that only men take part in. At least that's the situation in Bosnia [ ... ]. One of my acquaintances pointed out to me that this is only a tradition, which has nothing to with Islam." (Selma)

Religious rules and regulations that are viewed by more traditionally-minded and conservative believers as self-explanatory and in a sense 'natural' must certainly be allowed to be open to critical questioning by adherents of an open religiosity. And at times this may lead to practical consequences, such as in the form of observance, so that women can also participate in the Friday prayer service in the mosque. That is because they, like the interviewee Selma, perceive the notion that only male Muslims can recite the Friday prayer in a mosque to be a tradition —one whose rationale is solely social in origin, not religious or theological.

However, for the sake of completeness, it is necessary to mention that participation by female Muslims in the Friday prayer is by no means readily possible in every mosque and in every 'ethnic' community. Although as a rule their participation is not explicitly prevented by community members or the Imam, there are nonetheless numerous obstacles lying along this path. Usually, for this to become a reality, the active support of the Imams is required. But those Imams do not enjoy a completely free hand in the mosques where they are employed; rather, they are dependent in what they do on the agreement and support of the mosque community (Aslan et al. 2015).

Irma, another interviewee, a member of the second migration generation, with a Bosnian family background and the possessor of an Austrian passport, reported on an attempt along these lines in a mosque in Carinthia, which was however only of short duration. According to the young woman, an Imam whom she considered to be progressive wanted to also open up the Friday prayer to female Muslims, but these women did not make corresponding use of that possibility, and soon after they chose to stay away permanently. This was due inter alia to the incompatibility of attendance at the Friday prayers with preparing the family meal following the service at the mosque-since they bore sole responsibility for the household.

Tijana-a young convert to Islam living in Carinthia, from a Serbian family background-added that in principle she would be pleased to take part in the Friday prayers, but that she doesn't, due to the limited space in the mosque in her residential neighborhood. She commented that the prayer rooms had far too little space and that she also tended to shy away from the glances of the male Muslims participating in the prayer, and from the fact that physically they were so near to her: "Really, there are only men there and I don't wish to be stared at. Then I feel uncomfortable when I'm going to pray. And besides that, I'm always the only woman there." (Tijana)

In overview, two tendencies emerge in the form of practice of open religiosity in regard to dealing with religious duties and rules and regulations. These tendencies serve to differentiate open religiosity from other forms of Muslim everyday religious practice. On one hand, there is a push toward renegotiating religious traditions. Thus, for example, there is increased participation by women at Friday prayers in mosques (with the factual restrictions mentioned). On the other, evident is a reinterpretation of specific religious regulations and rules. In the everyday practice of open religiosity, religious regulations are being questioned-in particular when it comes to dealing practically with the ritual obligatory prayers. Although, to a certain extent, religious duties continued to be fulfilled, people place great concomitant stress on the value of self-determination and autonomy. 


\section{Perspectives and Conclusions}

Through the lens of our multi-perspectival approach, which encompasses both a qualitative and quantitative empirical analysis and interconnects the two, we have been able to achieve concrete and differential insights into the broad, multi-layered spectrum of religious concerns among Muslims. In doing so, we have engaged in a shift in perspective, avoiding an alienating discourse that goes over the heads of those under study; instead, we have made those individuals themselves the point of departure of the analysis. The contours of the complex of Muslim religiosity in Austria emerge into analytical view initially only by investigating how such religiosity is translated into daily life in the form of everyday religious practice. On second glance what strikes the researching eye is the range of diversity. Thus, highly religious attitudes and modes of behavior in everyday life are by no means always the same; rather we can discern striking differences in respect to the approach to religiosity and the understanding of religious rules and regulations and the pillars of Islam.

Our mixed-methods design enabled us to reconstruct open religiosity as one of various possible ways of dealing with religion in everyday life that to date has been accorded but little attention in research. We succeeded in uncovering the more precise nature of this form of practice in our study due to the correct balance of our sample, because we did not interview solely Muslims organized in mosque associations and religious facilities, as often was the case in earlier inquiry. Rather, we intentionally examined the everyday religious practice of those Muslim individuals who rarely or never enter a mosque.

Open religiosity is fundamentally an expression of the fact that religious affiliation and patterns of action in everyday practice are in constant flux. Consequently, the form of practice itself is by no means static; it is subject to dynamics of change. In some cases, open religiosity is also quite clearly a temporally limited phenomenon that also can undergo partial transformation in connection with major events in a person's life, such as marriage or the advent of parenthood. In addition, the form of practice is bound up with temporal, social, geographic and cultural contexts. This becomes evident in the fact that this form of practice is widespread most particularly among Muslims of the second or third migration generation, born and bred in Austria. Their socialization and concrete familiarity with West European living conditions and standards also has consequences for the ways people deal with religion. Generally speaking, in open religiosity the shaping influence by the so-called societies of origin is relativized; this is an influence that tends to play a more central and shaping role among persons of the first migration generation. Rather, the shaping power of the local here and now comes to gain greater traction and importance for the form of religious practice.

Thus, liberal, cosmopolitan aspects are reflected in religious practice, traditional religious authorities undergo transformation, and religious rules and regulations are questioned. Open religiosity is marked by an internal lack of homogeneity in respect to citizenship affiliation and consciousness, educational backgrounds, and also what communities of Islamic faith and diverse denominations one may be associated with. Research reveals a low level of denominational orientation among the subjects investigated. Commonalities and shared features between individuals spring from the degree of religiosity involved and the social value orientations they profess but are less influenced by a shared theological denomination or school of Muslim law. In defining their own religiosity, individuals refer less to classic theological elements of faith; rather, decisive are the concrete grassroots realities in their personal lives. The individuals themselves thus take the religious power of interpretation into their own autonomous hands. The form of practice is represented and lived in a self-determined manner. This is consistent with analyses by Werner Schiffauer, who pointed out that members of the successor generation often do not practice a defensive mode of religiosity as is common among their parents and grandparents (Schiffauer 2004, p. 351), but rather adhere in daily practice to an open, emancipative and self-determined religiosity.

The findings of this study provide strong evidence that the preponderant proportion of Muslims in Austria do not define themselves by means of conventional and classic theological contents of faith, but rather approach this from the matrix of their own life realities. They see themselves as mature, 
responsible citizens who, from a range of different elements, confidently piece together and shape their everyday religious practices. They have taken the power of interpretation of their faith into their own hands, as especially demonstrated in looking at the religious orientations of the successor generation. We require a theology that recognizes and takes seriously the changed realities of life of the persons practicing Islam, and on that basis projects a theology in keeping with the times-a theology that in this manner creates a different consciousness in respect to religious diversity and furnishes new perspectives and horizons for religious education.

Author Contributions: Both authors contributed to the interpretation and analysis of the empirical data. J.K. conceptualized the article and wrote the first draft. E.Y. reviewed the preliminary version and developed methodological and theoretical perspectives. J.K. finalized and edited the paper.

Funding: The publication of this article has been funded in part by the University of Innsbruck.

Conflicts of Interest: The authors hereby declare that there exist no conflicts of interest whatsoever.

\section{References}

Amiraux, Valérie. 2006. Speaking as a Muslim. Avoiding Religion in French Public Space. In Politics of Visibility. Young Muslims in European Public Spaces. Edited by Gerdien Jonker and Valérie Amiraux. Bielefeld: Transcript, pp. 21-52.

Ammerman, Nancy T. 2007. Introduction: Observing Modern Religious Lives. In Everyday Religion. Observing Modern Religious Lives. Edited by Nancy T. Ammerman. Oxford: Oxford University Press, pp. 3-18.

Aslan, Ednan, Evrim Ersan Akkilic, and Jonas Kolb. 2015. Imame und Integration. Wiesbaden: Springer.

Aslan, Ednan, Jonas Kolb, and Erol Yildiz. 2017. Muslimische Diversität. Ein Kompass zur religiösen Alltagspraxis in Österreich. Wiesbaden: Springer.

Bundesamt für Migration und Flüchtlinge. 2009. Muslimisches Leben in Deutschland. Forschungsbericht 6 im Auftrag der Deutschen Islam Konferenz. Nuremberg: Bundesamt für Migration und Flüchtlinge.

Creswell, John W., and Vicki L. Plano Clark. 2007. Designing and Conducting Mixed Methods Research. Thousand Oaks: Sage.

Dessing, Nathal M. 2013. How to Study Everyday Islam. In Everyday Lived Islam in Europe. Edited by Nathal M. Dessing, Nadia Jeldtoft, Jørgen S. Nielsen and Linda Woodhead. Farnham: Ashgate, pp. 39-52.

Diekmann, Andreas. 2010. Empirische Sozialforschung. Grundlagen-Methoden-Anwendungen, 4th ed. Reinbek: Rowohlt.

Gennerich, Carsten. 2010. Empirische Dogmatik des Jugendalters. Werte und Einstellungen Heranwachsender als Bezugsgrößen für religionsdidaktische Reflexionen. Stuttgart: Kohlhammer.

Gennerich, Carsten. 2016. Religiosität muslimischer Jugendlicher. Empirische Befunde und theologische Perspektiven. In Islamische Religionspädagogik in multiplen Perspektiven. Edited by Yaşar Sarıkaya and Adem Aygün. Münster: Waxmann, pp. 199-219.

Glock, Charles Y. 1969. Über die Dimensionen der Religiosität. In Kirche und Gesellschaft. Einführung in die Religionssoziologie II. Edited by Joachim M. Matthes. Reinbek: Rowohlt, pp. 150-68.

Göle, Nilüfer. 2016. Europäischer Islam. Muslime im Alltag. Berlin: BpB.

Goujon, Anne, Sandra Jurasszovich, and Michaela Potančokova. 2017. ÖIF-Forschungsbericht. Demographie und Religion in Österreich. Szenarien 2016 bis 2046. Vienna: Österreichischer Integrationsfonds.

Hall, David D. 1997. Lived Religion in America. Toward a History of Practice. Princeton: Princeton University Press.

Heine, Susanne, Rüdiger Lohlker, and Richard Potz. 2012. Muslime in Österreich. Geschichte—LebensweltReligion-Grundlagen für den Dialog. Innsbruck: Tyrolia.

Huber, Stefan. 2003. Zentralität und Inhalt. Ein neues multidimensionales Messmodell der Religiosität. Opladen: Leske \& Budrich.

Jeldtoft, Nadia. 2009. On Defining Muslims. In Yearbook of Muslims in Europe. Volume I. Edited by Jørgen S. Nielsen, Samim Akgönül, Ahmet Alibašic, Brigitte Maréchal and Christian Moe. Leiden: Brill, pp. 9-14.

Jeldtoft, Nadia, and Jørgen S. Nielsen. 2011. Introduction: Methods in the Study of 'Non-Organized' Muslim Minorities. Ethnic and Racial Studies 34: 1113-19. [CrossRef]

Kermani, Navid. 2009. Wer ist Wir? Deutschland und seine Muslime. Munich: C. H. Beck. 
Khorchide, Mouhanad. 2007. Die Bedeutung des Islam für Muslime der zweiten Generation. In Leben in zwei Welten. Zur sozialen Integration ausländischer Jugendlicher der zweiten Generation. Edited by Hilde Weiss. Wiesbaden: VS Verlag für Sozialwissenschaften, pp. 217-44.

Klinkhammer, Gritt. 2000. Moderne Formen islamischer Lebensführung. Eine qualitativ-empirische Untersuchung zur Religiosität sunnitisch geprägter Türkinnen der zweiten Generation in Deutschland. Marburg: Diagonal-Verlag.

Kolb, Jonas. 2017. Religiöse Praxisformen junger MuslimInnen in Österreich im Alltag. Virtualisierungstendenzen, religiöse Bricolage und der Prozesscharakter des religiösen Lebens. Österreichisches Religionspädagogisches Forum 25: 74-88.

McGuire, Meredith B. 2008. Lived Religion. Faith and Practice in Everyday Life. Oxford: Oxford University Press.

Nielsen, Jørgen S. 2013. Concluding Reflections: Everyday Lived Islam and the Future of Islamic Studies. In Everyday Lived Islam in Europe. Edited by Nathal M. Dessing, Nadia Jeldtoft, Jørgen S. Nielsen and Linda Woodhead. Farnham: Ashgate, pp. 163-77.

Ornig, Nikola. 2006. Die Zweite Generation und der Islam in Österreich. Eine Analyse von Chancen und Grenzen des Pluralismus von Religionen und Ethnien. Graz: Grazer Universitätsverlag.

Orsi, Robert A. 1985. The Madonna of 115th Street. Faith and Community in Italian Harlem, 1880-1950. New Haven: Yale University Press.

Özıștk, Sakin. 2016. Intergenerational Changes in the Religiosity of Turkish Islamic Immigrants in Contemporary Germany. A Qualitative Analysis Using the Faith Development Interview. Bielefeld: Universität Bielefeld.

Radtke, Frank-Olaf. 2011. Kulturen sprechen nicht: Die Politik grenzüberschreitender Dialoge. Hamburg: Hamburger Edition.

Schiffauer, Werner. 2004. Vom Exil- zum Diaspora-Islam. Muslimische Identitäten in Europa. Soziale Welt 55: 347-68. [CrossRef]

Schiffauer, Werner. 2010. Nach dem Islamismus. Eine Ethnographie der Islamischen Gemeinschaft Milli Görüş. Berlin: Suhrkamp.

Schreier, Margrit. 2010. Fallauswahl. In Handbuch Qualitative Forschung in der Psychologie. Edited by Günter Mey and Katja Mruck. Wiesbaden: VS Verlag für Sozialwissenschaften, pp. 238-51.

Schwartz, Shalom H., Gila Melech, Arielle Lehmann, Steven Burgess, Mari Harris, and Vicki Owens. 2001. Extending the cross-cultural validity of the theory of basic human values with a different method of measurement. Journal of Cross-Cultural Psychology 32: 519-42. [CrossRef]

Spielhaus, Riem. 2011. Wer ist hier Muslim? Die Entwicklung eines islamischen Bewusstseins in Deutschland zwischen Selbstidentifikation und Fremdzuschreibung. Würzburg: Ergon.

Tietze, Nikola. 2001. Islamische Identitäten. Formen muslimischer Religiosität junger Männer in Deutschland und Frankreich. Hamburg: Hamburger Edition.

Weiss, Hilde, and Robert Strodl. 2016. Muslimische Milieus. Religiöse Bindung, Geschlechterbeziehungen und säkulare Orientierung. In Muslimische Milieus im Wandel. Religion, Werte und Lebenslagen im Generationenvergleich. Edited by Hilde Weiss, Gülay Ateş and Philipp Schnell. Wiesbaden: Springer, pp. 51-81.

Yildiz, Erol. 2018. Vom methodologischen Orientalismus zur muslimischen Alltagspraxis. In Islam in Europa. Begegnungen, Konflikte und Lösungen. Edited by Zekirija Sejdini. Münster/New York: Waxmann, pp. 61-78.

Yildiz, Erol. 2019. Ideen zu einer transreligiösen Bildung. Kontrapunktische Betrachtungen. In Interreligiöse Bildung zwischen Kontingenzbewusstsein und Wahrheitsansprüchen. Edited by Zekirija Sejdini and Martina Kraml. Stuttgart: Kohlhammer, in press.

(C) 2019 by the authors. Licensee MDPI, Basel, Switzerland. This article is an open access article distributed under the terms and conditions of the Creative Commons Attribution (CC BY) license (http://creativecommons.org/licenses/by/4.0/). 